\title{
Merger of Private Universities: Empirical Study STAI Become FAI of Muhammadiyah University Bandung
}

\author{
Sitti Chadidjah ${ }^{1)}$, Muhamad Tisna Nugraha ${ }^{2}$, Qiqi Yulianti Zaqiah ${ }^{3)}$, Supiana ${ }^{4)}$ \\ ${ }^{1}$ Universitas Muhammadiyah Bandung, Indonesia \\ ${ }^{2}$ Institut Agama Islam Negeri Pontianak, Indonesia \\ ${ }^{3,4}$ Universitas Islam Negeri Sunan Gunung Djati Bandung, Indonesia \\ Email: sittichadidjah@staim-bandung.ac.id
}

Received: 18-07-2021

Revised: $30-10-2021$

Accepted: 08-11-2021

Article info

Abstract

Keywords:

Merger, Institution, Process, STAI

Kata kunci:

penggabungan, proses, lembaga, STAI
The number of private universities in Indonesia is more than universities in the most populous country in the world, but it is not accompanied by good quality. This research is an empirical study with a descriptive, qualitative research approach. Technical data collection through documents, and observations of the process of unification of STAI and Muhammadiyah University. The unification of these two institutions is in one foundation, namely Muhammadiyah. In this merger process, the Ministry of Education and Culture and the Ministry of Religion are involved. The Chairperson of the Association of Indonesian Private Universities strongly supports the merging of two or more universities to reduce the number, facilitate coaching, and improve the quality of higher education. The first merger process was carried out by the Ministry of Education and Culture after the filing and visitation procedures were completed in writing and the visit of the LLDIKTI chairman followed by submission to DIKTIS (Directorate of Islamic Higher Education). This article aims to prove empirically about the implementation of the Ministry of Education and Culture's policies and the Decree of the Directorate of Islamic Higher Education regarding the merger of two or more universities, 2) information that the merging process of PTKAI and PTU is not easy.

Abstrak
Jumlah perguruan tinggi swasta di Indonesia lebih banyak dibanding dengan perguruan
tinggi di negara terpadat di dunia, namun tidak diiringi kualitas yang baik. Penelitian
ini merupakan studi empiris dengan pendekatan penelitian kualitatif deskriptif. Teknis
pengumpulan data melalui dokumen, dan observasi terhadap proses penyatuan STAI dan
Universitas Mubammadiyah. Penyatuan dua lembaga ini berada pada satu yayasan yaitu
Mubammadiyah. Pada proses penggabungan ini, mengikutsertakan Kementrian
Pendidikan dan Kebudayaan dan Kementrian Agama. Ketua Asosiasi Perguruan Tinggi
Swasta Indonesia sangat mendukung penggabung dua perguruan tinggi atau lebih
tujuannya untuk mengurangi jumlah, memudabkan pembinaan, dan meningkatkan
kualitas perguruan tinggi. Proses penggabungan pertama dilaksanakan oleh
Kemendikbud, setelah prosedur pemberkasan dan visitasi selesai yang dinyatakan secara
tertulis dan kunjungan ketua LLDIKTI, dilanjutkan pengajuan penggabungan ke
DIKTIS (Direktorat Pendidikan Tinggi Islam). Artikel ini bertujuan membuktikan
secara empiris tentang 1) implementasi dari kebijakan Kemendikbud dan Keputusan
Direktorat Pendidikan Tinggi Islam tentang penggabungan dua perguruan tinggi atau
lebih, 2) menginformasikan proses penggabungan PTKAI dan PTU tidak mudah.




\section{INTRODUCTION}

Merger or we are familiar with the merging of two or more universities, whether it's the merger of two high schools, or two institutions, or even two universities, emerged when there was a ministry of research, technology and higher education. When there was a ministry of research, technology, and higher education, we began to see mergers of two or more universities, whether it was two high schools, two institutes, or even two universities. The ministry's main goals are to 1) improve the quality of campus and university administration, 2) improve the quality of university graduates, and 3) develop the institution or educational institution. Improving the quality of higher education is a top priority considering that higher education is a service industry such as hospitals and others. Services in the context of college are lectures (Nur Khoiri, 2016).

"He fully supports the government's attempts to minimize the number of universities, with the goal of increasing education quality," according to Bambang Djatmiko, Chairman of the Association of Indonesian Private Universities. According to Bambang Djatmiko, Chairman of the Association of Indonesian Private Universities, "he strongly supports the government's efforts to reduce the number of universities, with the aim of improving the quality of education, and facilitating development "(Yanita Petriella) Mergers in the context of industry, or the economy are carried out when one company is declared small, or a company is sick, or is difficult to develop, or is experiencing a decline in production. The purpose of these mergers is often related to efficiency and effectiveness. For example, a company that is experiencing low production can be merged into a company that is productive and has good benefits. In general, the purpose of this merger is to heal the ailing company, so that it is as healthy as the existing companies. Another possibility is that the merger of two sick companies will facilitate the healing process, because it is handled, for example, by only one consultant. The word that is often used in this context is concatenation. Likewise, what is expected from the merger of private universities in Indonesia. This merger is expected to be able to improve the quality of service which we know as total quality management (Sitti Rabiah, 2019)

In comparison to China, which has a population higher than Indonesia and has 2825 universities, it is possible that Indonesia has about 4586 universities. There are 400 public universities and 4186 private universities in the United States. The aim of 1000 institutions were met, with 65 universities joining; however, due to the lack of incorporation criteria, this number may be cut further. The difficulty for private colleges to meet 1) administrative criteria, particularly land acreage, is one of these impediments. According to the terms of the merger, the university must have 1000 square meters of land, the Institute is 8000 square meters, and 5000 square meters for high schools and others, 2) there must be 1000 square meters of land for the university, the Institute is 8000 square meters, and 5000 square meters for high schools and others, 3 ) there are 9 standards that must be met.

There were 6000 public and private universities at the time, according to the minister of religion. Indonesia's goal is to become the world's center of Islamic education with this number. There are 55 universities in Egypt, 60 universities in Saudi Arabia, and 35 Islamic universities in Malaysia. The large number of PTKIS has not been matched with the quality of implementation; this is unfinished business. Even though the regulatory instruments for the merger currently exist, the Directorate of Islamic Higher Education has not yet participated in this merger process. For example, a PTU that wishes to establish an Islamic study program will be granted a permit if the PTU has the status of a university. or vice versa PTKIS joins PTU.

It is true that the statement above states that there are simple or complicated administrative requirements, however combining PTKIS into PTU is not easy. The writers discovered the objective of 1000 institutions merging in 2019 by reading stories in electronic newspapers, however it has not realized. Vision, mission, goals, and objectives; the product and impact of the Tridharma; education; study; community service; student; Human Resources (HR); finance, facilities, and infrastructure; and governance and cooperation are all part of Standard 9 administrative criteria. Meanwhile, PTKI must meet three criteria in order to join PTU: infrastructure, education, and 
student standards. The program was issued by the Ministry of Research, Technology and Higher Education in 2017 and in 2020 the Ministry of Education and Culture issued a similar regulation in the form of Permendikbud No 7 of 2020 concerning the establishment, change, dissolution, revocation of universities.

The absorption of PTKIS into PTU, as well as research at the PTKIS institute of the Islamic High School-Muhammadiyah, which was merged into the University of Muhammadiyah Bandung, will be discussed in this article. The policy analysis of the Minister of Education and Culture Number 7 of 2020, as well as the Decree of the Directorate of Higher Education Number 3069, which is a development of Permenristek Dikti Number 100 of 2016 concerning the Establishment, Amendment, Dissolution of State Universities, and the Establishment, Amendment, Revocation of Private Universities Permits, includes two indicators in the evaluation policy analysis: 1) effectiveness with revocation to the success of one alternative, 2) adequacy with regard to the level of satisfaction between policy products and the expected results, 3) equity is closely related to policy equity, do not let policy products This is enjoyed by certain groups of people, and vice versa. 4) responsiveness, user satisfaction with policy implementation, 5) accuracy refers to policy objectives. (Nanang Fattah 235) This study will select one of five indicators, namely the effectiveness and implementation of the Ministry of Education and Culture and Ministry of Religion policies regarding the merging of two universities. Furthermore, the discussion will answer the formulation of the problem whether the implementation of Permendikbud number 7 of 2020 and the Decree of the Director General of Islamic Education number 3069 regarding unification PTKIS has been effective.

\section{RESEARCH METHOD}

The discussion in this study uses a qualitative research methodology approach with descriptive techniques. The discussion will lead to the concept of policy analysis, which is limited to the evaluation stage, and its implementation in the field based on a study of the incorporation of STAI into universities. Data collection is done by studying documentation in the form of program profiles, statutes, forms of educational institutions.

Data analysis combines information from STAI and other sources such as electronic newspapers, the Ministry of Education and Culture's website, and the Ministry of Religion's website. In this scenario, data was collected in the form of hard copies and soft copies for analysis. According to Newman, social science research is pervasive and has an impact on people's daily lives. (Neuman) According to Creswell, research is a series of steps used to gather and analyze data in order to gain a better understanding of a topic or situation. (Creswell) Newman also shown that qualitative approaches have the ability to shape social reality by focusing on interacting processes. Newman said that social science research is pervasive and affects the daily lives of people around the research.(Neuman) Research according to Creswell is a process of steps used to collect and analyze information to increase understanding of a topic or issue.(Creswell) Newman also revealed that the characteristics of a qualitative approach are shaping social reality, focusing on interactive processes and events, authenticity of key factors, assessing current and explicit, mixed theory and data, made based on situations, cases, few subjects, thematic analysis, and researchers involved.(Neuman) 


\section{RESULTS AND DISCUSSION}

Persyarikatan Muhammadiyah is popular with a large number of educational institutions covering all levels of education from kindergarten to college. Every district in West Java has a Muhammadiyah College, as well as in East Java, Central Java, Kalimantan, Nusa Tenggara, Irian Jaya. In general, it can be said that where there is a state campus there is a Muhammadiyah University. Not only in big cities such as provinces, but also in municipalities and regencies such as Bulukumba, a regency city which is quite far from the capital city of Makassar, the authors found Muhammadiyah schools, campuses, and hotels.

There are kindergartens, elementary schools, junior high schools, high schools, and Muhammadiyah colleges in every city, district, and municipality. how noble the teachings of Kiai Haji Ahmad Dahlan are that, in remote parts of the country, Muhammadiyah cadres have established charities in the field of education. Bandung has three Muhammadiyah universities: STAI, STIE, and Aisyiah college. Muhammadiyah oversees two universities, STAI and STIE, while Aisyiah, as a women's organization, oversees one university, namely STIKES. Aisyiah also founded a university that was originally STIKES. Aisyiah, now it is Aisyiah University. Muhammadiyah University is a combination of Muhammadiyah University, STAI, and STIE. In this article the author focuses on STAI Muhammadiyah.

This Islamic College is the first Muhammadiyah College in Bandung which was established in 1987. Consistently devoted to producing enlightened superior human beings, STAI has the goal of educating students who have firm faith, integrity, care, responsibility, professionalism, and ability. adapt to changing times. STAIM's belief is that it is solemn in the world of education that has an important mandate, namely human beings with character and progress. Once named the tarbiyah College of Science (STIT), which has a study program in Islamic Education, it is in great demand by both Muhammadiyah residents and Muslims throughout West Java. In its development STIT in 1995 changed to STAI with the addition of the Abwal al Syabshiyyah study program for the S1 program. Three years later, the Islamic Economics Muamalah (MEI) study program was established and the Ibtidaiya Madrasah Teacher education program at the D2 level. Due to several factors, only PAI study programs can survive. In 2014 it opened a new study program, namely sharia economics, in 2015 established a new study program for Early Childhood Islamic Education (PIAUD), Islamic Broadcasting Communications (KPI), and Abwal Al-Syabsyiyah which was converted into HKI (Islamic family law), all at the undergraduate level. Until today, STAI has five study programs.

The journey of these five study programs is certainly not easy, the obstacles that arise in the PAI study program which used to be a popular study program began to shift along with the emergence of external factors, namely first, the incessant improvement of the quality of kindergarten teachers, then requiring them to take undergraduate courses, second, the popularity of the PAI study program as a first study program. the only one in the field of religion teachers for all levels, the third the emergence of new study programs, namely the PIAUD study program and the PGMI study program. These three external factors have an impact on the decline in public interest in Islamic religious education study programs.

Meanwhile, the Islamic economics study program has an increasing number of enthusiasts. This is due to 1) the tendency of the Muslim community to turn to halal products, and the trend to stay away from usury, 2) the birth of Islamic banks, throughout Indonesia, 3) to fulfill the resources in Islamic banking. This dynamic in society contributes to the number of Islamic economics students. Moreover, every special mosque in the city of Bandung has a program to educate mosque staff, especially those in charge of the mosque's zakat collectors, who are required to master sharia economics so that they are able to answer the challenges of the current Islamic economy. must study Islamic economics.

The early childhood Islamic education study program has experienced a surge in interest today, due to 1) the issuance of prerequisites for kindergarten teachers (kindergarten or equivalent) to be at level 1.2) incentive assistance for kindergarten teachers who are then used for college, 3) 
attention government towards early childhood education, led to the birth of kindergarten from a foundation formed by the community. This factor is very influential on the fans of the PIAUD study program. STAI Muhammadiyah has students consisting of TK/RA teachers with a total of 400 data for 2018-2019. This made a good contribution to the development of STAI.

In contrast to the study program of Islamic Family Law and Islamic Broadcasting Communications, in its development the community was less interested. To attract prospective students, the campus holds a special scholarship program, free of tuition fees until semester 7 with certain conditions. Although the number of students is small, the lectures proceed normally. This case seems commonplace. The same thing was stated in the main report of the 2017 Kopertis Regional IV Bulletin that all campuses have problems, one of which is the lack of student interest in certain study programs.

The obstacles faced by STAI are not only the number of students, the quality of lecturers, what is more visible is the limited campus land, and lecture buildings, which lead to services that are less than optimal in the lecture process. Lecture buildings that always maintain the cleanliness of classrooms, bathrooms, and cleanliness in the campus environment, are limited in the number of rooms. In 2018 and 2019 the PIAUD study program received many students who were all active teachers, the lecture schedule was Friday afternoon and Saturday. Likewise, the Islamic economics study program and the PAI study program. Due to the limited availability of lecture rooms, it is not uncommon for lectures to use SMP/SMA or SD classrooms. Students sometimes can and do not accept the situation of having to study in the Muhammadiyah Elementary School or Middle School, High School, Muhammadiyah study rooms whose buildings are adjacent to STAI. In this situation, the lecturers always direct students to better understand the importance of essence, rather than existence, in this case, lecture facilities. After 30 years, the Bandung Muhammadiyah Islamic High School was established with all its advantages and disadvantages, in 2019 it carried out a merger process or merger with universities. University of Muhammadiyah Bandung (UM Bandung) is an educational institution under the Muhammadiyah Organization in this case the Representative of Muhammadiyah West Java. This campus was founded five years ago and is located on Jalan Palasari. Then occupying waqf land, Muhammadiyah University stands on Soekarno Hatta Street, Bandung.

Muhammadiyah University of Bandung has 18 study programs and 4 faculties. The addition of two faculties in 2019 made UM Bandung strong. The two faculties are the Islamic Sciences faculty, which is the development faculty of the Islamic High School (STAI) and the Economics Faculty. Development of the Muhammadiyah College of Economics. These two faculties bring everything, namely the number of students. The Faculty of Islamic Sciences contributed 950 students, and the Faculty of Economics and Management contributed 750 students. This large number of students is a campus asset, and when combined, UM Bandung has thousands of students. Of course, this has a good impact, namely increasing public trust, so they want to send their children to school. In this discussion, it will be limited to the incorporation of STAI Muhammadiyah at UM Bandung, where the author works.

The merger of three universities, namely the University of Muhammadiyah Bandung, the Islamic College of Muhammadiyah, and the College of Economics within the Muhammadiyah organization in the West Java region was warmly welcomed by LL Dikti. Because this is in accordance with Permendikbud number 7 of 2020, and the work plan of LL Dikti, namely the merger of private universities. The merging process is carried out first by the institution, in this case, which has an adequate and already established building, namely the University of Muhammadiyah Bandung. In the merger of these three universities, they are included in the category of universities that have the same vision. So that merging is easier. The merging procedure follows the conditions set by the LL Dikti. Merger procedures 1) all files are uploaded to Simlemkra, 2) data will be validated by BAN-PT, if it turns out that there are incomplete data, the PTU will be asked to complete 2) Universities that apply are waiting for results 3) visit preparation, in principle this activity is an activity to check the accuracy of real data with data that is uploaded, 
4) the visit is carried out at the PTU that submits (in this case UMB) then the visit is carried out at UMB. PTU prepares files in accordance with what is uploaded by the university, in this case UMB. When the visit is still lacking in files, the visitor gives us time to complete at least 10 days after the visit. All complete files, PTU awaits the decision of LL Dikti. What we have estimated is approximately 2 weeks after the repair files are completed, then LL Dikti will submit an official merger letter. So, at the University of Muhammadiyah syah and listed as a university that combines two private universities.

This merging process does not stop here, STAI, which is under the coordinator of the Cooperatives Region II West Java, must also go through a merger process which includes 1) merging two STAI universities into UM Bandung, 2) completing merging requirements, 3) uploading complete files to the Diktis portal, then all files are validated, if there are deficiencies, they must be completed, 4) visit to the campus resulting from the merger that has been legalized by DIKTI. All DIKTI and DIKTIS procedures are listed in the DIKTI manual, while DIKTI procedures are regulated in a letter regarding the procedures for establishing and changing PTKIS. The merger of universities under the auspices of DIKTI, namely STIE Muhammadiyah to UM Bandung takes place automatically, while STAI to UM Bandung must go through a new procedure at DIKTIS. Unlike usual for the January-February 2021 period, the portal is closed, and will be opened in May 2021. The file for merging UM Bandung and STAI has not been uploaded, because the portal is temporarily closed, until May 2021. Unfortunately, DIKTIS does not offer an alternative, because This will delay the process of opening a new study program that has been carefully planned

This merger aims to improve the quality of campus administration, so as to create consistency based on 1) common perspectives on quality education, 2) common ideologies of life, 3) common goals, namely creating quality universities. The main thing is to also follow government regulations, in this case the Ministry of Education and Culture Number 100 of 2016 concerning the merger of universities and the decision of the PP Muhammadiyah Higher Education Council regarding the establishment of the University of Muhammadiyah Bandung. College Incorporation Overview. Improved campus administration can be interpreted as an increase in education that has been proven to be able to improve the quality of life of human resources in a nation (Eka Prihatin Disas, 2017)

The government through the Ministry of Research, Technology and Higher Education issued regulations for the merger/merger of universities in Indonesia. With the aim that the implementation of the university is effective and efficient. Prof. Asep Saifudin said that there are two types of consolidation that can be applied in the merger process: 1) voluntary mergers are applied to universities that have the same level and 2) merger acquisitions of several small private universities that have the same characteristics as large universities. Like Muhammadiyah College. This merger is prioritized for several universities that come from the same foundation, such as in this case STIE and STAI Muhammadiyah Bandung. However, for universities with different foundations, it is difficult to combine them because they have different principles and goals. He also said that merging these universities was not easy, problems arose such as 1) each foundation had a unique history of establishing higher education institutions and wanted to perpetuate it, 2) no agreement was reached between the two universities. Both of these things cause the merger process to be slow, even if it doesn't happen.

The analysis is defined as "An approach and methodology for design and identification of possible alternatives in respect to complex policy issues" (Solichin Abdul Wahab 40). Along with that William Dun said, "policy analysis is a practical intellectual activity aimed at creating, critically assessing and communicating knowledge about the policy process". At the beginning of the birth of the Ministry of Research, Technology and Higher Education, we were shocked by the emergence of private universities which in further research were not healthy in development, traded diplomas, did not hold lectures but were able to pass, lectures were held in shop houses and other odd things. This is the first time the academic field has dealt with the authorities. 
In 2016 the Ministry of Research and Technology and Higher Education issued regulation Number 100 of 2016, concerning the establishment, amendment, dissolution of PTS and establishment, amendment, revocation of PTS permits. The issuance of the Permenristek Dikti is accompanied by the issuance of technical instructions on acquisitions and mergers. At that time at the 2017 higher education development event in Bandung, which was held by Kopertis Region IV West Java, LL Dikti targeted to reduce 1000 private universities in Indonesia. Until 2018, the Ministry of Research, Technology and Higher Education managed to merge 150 private universities.

This research is an implementation of the Ministry of Research, Technology and Higher Education policies Number 100 of 2016 and number 7 of 2020 and regarding the merger of private universities. The obstacles faced in addition to the two classic things that have been described above, are 1) not meeting the requirements, for example combining two academic diplomas, both of which only have 8 majors, while the university requirement must have 10 new study programs with strata 1 tiers, 2) other difficulties with administrative completeness namely the difficulty of lecturers who are relevant to the study program.

The government, to make it easier for administration, continues to update the merger requirements, namely the Dikti Licensing Revolution (2019) for the opening of new study programs and the merger is only 15 working days. For tertiary institutions that will be merged, it is enough to prepare a proposal with the criteria of 1) curriculum, 2) infrastructure, 3) human resources, as explained by the Directorate General of Science and Technology Institutions and Higher Education Prof. Dr. Ir. Yudhy Harini Bertham. Mergers are a necessity in the midst of many universities in the country, but what is more important is a high quality, healthy university. The course of the merger regulation changes according to the conditions that occur, for example, by applying the number of students below 3000 , the university proposes a merger.

Private Islamic Universities based on data from the Higher Education are 1,246 spreading throughout Indonesia. Islamic Higher Education is commonly abbreviated as PTKIS, under the auspices of the Indonesian Ministry of Religion. Furthermore, at the technical level, it is carried out by the Directorate General of Islamic Higher Education (Diktis). Diktis has almost the same role as LL Dikti, which is to serve and ratify Islamic universities. For example, Diktis gives permission for the establishment of new universities. In mid-2020 the Ministry of Religion through Diktis published 17 private universities spread throughout Indonesia.

Regulation of the Ministry of Religion through Islamic higher education commonly called Diktis issued a policy on the merger of Islamic private universities through the Decree of the Director General of Islamic Higher Education number 3069 of 2018 concerning technical instructions for permits for establishment, change and revocation of permits for private Islamic religious universities. The establishment includes the submission of a new university, the submission of a new study program. Changes and revocation of permits include changes in the names of universities, which are caused, among others: 1) an increase in the status of higher education, for example from STIT, Tarbiyah High School of Science which has a special teaching program, to STAI, Islamic high school which has cognate study programs, for example PAI study program, and Eksyar study program. so next. 2) an increase in the status of a higher education institution from STAI to an institute for example IAID Darussalam Islamic Institute, then when this institute covers general and science study programs or anything other than the religious sciences group, the status of the college becomes an Islamic University. Islamic University is the highest status of the private Islamic higher education level.

Institutions that are given the mandate by the respective ministries, specifically in the field of university management. Structurally, both Dikti and Diktis have technical assistants in the regions or are extensions of the Dikti and Diktis who are the coordinators of regional universities known as the coordinators of private universities (Kopertis) and coordinators of Islamic universities (Kopertais). These two directorates have substantially the same working footing, namely Kemenritek Dikti number 100 of 2016 which has been updated to Kemendikbud number 7 of 
2020. However, having different orientations or tendencies, Dikti has a tendency to diagnose and combine private universities with the aim of becoming higher education institutions. healthy and strong so as to produce quality graduates as well. While Diktis has a tendency to allow or give birth to the establishment of new universities.

\section{Merger Policy Implementation}

Based on the analysis stages stated above, this research uses an approach at the policy implementation stage. An important sequence in policy formulation is policy implementation which is at the same time the most complicated and complex stage. Therefore, it requires serious cooperation from all parties (Elwijaya Fadiyah, Vivi Mairina, 2021). The complexity that occurs can be resolved through a hierarchical approach or can be interpreted as a small-scale (miniature) and granular concrete approach, which is an approach based on order interactions, which bring aspirations from the lowest order of society(Aulia Alfirzan, Yuris Nasri, 2021).

Meanwhile, in conveying argumentative information, the author uses an empirical and normative approach, namely by expressing the author's experience. Lester and Stewart, that policy evaluation can be distinguished in two different tasks, the first task is to determine whose consequences are caused by a policy by describing its impact. While the second task is to assess the success or failure of a policy based on predetermined standards or criteria (Akbar, 2016). Evaluation functions as Evaluation is a tool to observe the policy process. In the evaluation policy cycle, the final phase is marked by the question whether the policy has been effective? But in the reality this evaluation is considered a new chapter of a phase. If the policy is considered less effective, it will raise another question, namely whether the policy needs to be changed? Evaluation is a policy selection process through three aspects, namely desirability (attractiveness) whether the policies taken will benefit various stakeholders, have an impact on economic development and stability; and whether the policy is under the cultural principles or values and ideology of one nation. Affordability is closely related to the economy, and is an aspect of education spending that is more vulnerable to economic and political situations. Therefore, an economic scenario is needed. Feasibility, which includes the readiness of human resources to implement a new policy(Widya Sari, Andi Muhammad Rifki, 2020).

Success in policy implementation requires excellent communication. The basis and objectives of a policy need to be implemented through communication. Effective communication will determine the level of success. Therefore, in general communication is important, but truly perfect communication is difficult to achieve (Paraden Lucas Sidauruk, 2013).

Merger or merger emerged in the 19th century, before the first world war in the United States the first wave of mergers occurred simultaneously, many companies united with the aim of forming a monopoly on one or more commodities, products, and even certain policies, so that this monopoly triggered antitrust laws. The first world war ended the first antitrust wave. The second wave of mergers occurred in the 1920s, which had the character of vertical mergers. This period was marked by the merger of giant automobile companies such as Ford. This second wave ended in 1929 which was allegedly caused by the Great Depression. The occurrence of a third wave of mergers is called a merger of conglomerate. The concept of merger adopts from diversification, and development will be line business. The decline in the shares of conglomerate companies on the stock exchange was signaled the end of this third wave. The fourth wave occurred in the 1980s with the principle of disciplinary mergers, marked by the emergence of banking and financial services. The fifth wave in the 1990s was marked by the advancement of the world of banking and telecommunications. The factors of market deregulation, privatization, technology shock and the internet are very strong in this era, leading to the merger of the banking and financial services worlds. The current slowdown is allegedly due to the collapse of the internet shock and financial problems in the telecommunications world. (Josua Tarigan, Phd, CFP, CMA, CSRA et al. 7-9) 
Merger is a legal act carried out by several companies that will merge with other existing companies, so that the assets and liabilities of the merging companies are transferred to the company that accepts the merger (Josua Tarigan, Phd, CFP, CMA, CSRA et al. 7) Furthermore, the legal entity status of the merging company ends by law. This definition is based on Article 1 point 9 of the Limited Liability Company Law, for example in the telecommunication industry company Axis and XL, becoming one company, namely XL. Examples of university mergers occur in several Muhammadiyah universities. There are not many references that discuss this policy, the results of previous research provide the following discourse

1) Sumarto, Political Development and Policy on Islamic Education in Indonesia, reveals that policy analysis does not intend to replace politics by enforcing a kind of technocratic elite, such goals will not occur in institutions characterized by cognition, disjointed decisions, a tangled interpretation system, and organized anarchy. (Sumarto)

2) Muhammad Idrus, Evaluation of Government Policies in the Implementation of Islamic Religious Education, stated that there are educational matters at the ministry of education and culture that provide ideas, solutions for madrasas first. In the future, it is hoped that the idea of Islamic education should come from the Ministry of Religion, but if there are the same rules, they should be applied at the same time, formulation, and rules of the game. On the other hand, the Ministry of Religion and the Ministry of Education and Culture must work together, but if Islamic education is currently a supplementary part, the Ministry of Religion should shift that role as a substantial (determining) part. (Idrus 156)

3) La Mahidin, Thesis: Policy on Islamic Education in Indonesia, reveals that the Study of Islamic Education is understood to be limited to the characteristics of education with an Islamic background. The background of the birth of Law Number 20 of 2003 concerning the multi-factor National Education System; 1) religion, where the majority of the Indonesian people are Muslims, 4) the ideology of the state of Indonesia which has social justice for the community, 3) community development, there was a reform that became a turning point in the development of society, 4) the development of science and technology. The National Education System has significant implications for the growth and development of Islamic education in Indonesia. (La Mahidin 148)

5) Ni Nyoman Official, Ni Ketut Adi Mekarsari; Proceedings, Development of Private Higher Education Through SWOT Analysis revealed that education regulations have an impact on education in higher education. In the study of universities, various things were found; 1) Human resources are crucial, especially in facing competitiveness, 2) human factors, in this case students. Through a SWOT analysis, it provides benefits for determining strategic options in understanding the potential of private universities to survive in the future era of globalization. approaches in analyzing one policy, namely normative and descriptive approaches. The normative approach aims to provide ideas or ideas to decision makers. While descriptive culture aims to provide data as it is. (Rokim 60)

6) Cita Yustisia Serfiyani, Restructuring Private Universities as an Effort to Rebabilitate and Improve Institutional Quality, stated from a legal point of view, that the quantity of private universities in Indonesia is not comparable to the low quality of graduates. Efforts to streamline higher education can be pursued by restructuring, merging, consolidating, acquiring, and separating companies that are tailored to the characteristics of foundations and private universities. The right method in an effort to streamline universities is merger and consolidation. This study concludes that in order to obtain legal protection and the success of managers after restructuring, first, it is necessary to regulate the transfer of rights of the parties, secondly, new regulations are needed to support the merger or consolidation process. (Serfiyani 411)

The six articles above tend to explain that the Ministry of Education and Culture's educational regulations were followed by the Ministry of Religion such as regulations in Madrasahs and also the merger of religious universities into larger public universities. Merger of universities under two different ministries can be done by complying with various rules that apply in both institutions. If the implementation of this regulation is observed and implemented, even though 
this merger can be taken, it requires preparation time, the implementation is quite long. Hopefully this fact can be analyzed. The need for policy analysis to ensure that the policies to be taken are correct and based on optimizing the benefits of policies for the public, and benefiting policy makers. A policy analyst must have skills including 1) quick to focus on very central decision criteria, 2) the ability to analyze multi-disciplines and be able to master or access other sources of knowledge, 3) be able to analyze and make the right decisions, 4) be able to avoid the textbook approach. only to analyze policies, but to be able to use simple, precise, logical methods to design methods that do not yet exist, 5) be able to overcome uncertainties and express them with numbers, 6) be able to make simple and clear problem formulations, examine actual facts, position self to the user, 7) able to say "yes" and "no" to the proposal, able to provide a definition and analysis, 8) able to have high professional ethics. (Nugroho)

The time it takes for the merger of the two universities that are part of the two umbrella institutions of this country is not insignificant; it is moving slowly, despite the fact that there is still a digital data transfer process that takes time after the hard copy letter is received by the campus. As a result, I hope these two organizations revisit or reassess their discussions, particularly the digital data migration procedure, as stated in statement number 7 in this paragraph. However, as noted by Nugroho earlier, one must be able to make two types of decisions: first, normative decisions that follow established protocols, and second, non-normative decisions that are easy and logical. The meaning of this sentence means that it takes a simple method to produce a final goal. Meanwhile, policy evaluation is also an activity of estimating or assessing policies consisting of substance, implementation and impact. Activity evaluation is carried out in every policy process, therefore policy evaluation begins with the formulation of policy problems, the proposed program to solve policy problems, implementation and the policy impact stage (Sumarto: 2017)

The impact of this merger can be categorized in two ways, namely quantitative and qualitative, as explained above that there is a lack of interest in the IPR and KPI study programs, after the campus was merged there was an increase in interest in these two study programs. The number of students for the academic year 2020-2021 Odd semester of the HKI study program is 25 people and the KPI study program is 35 people. An increase in interest occurred in the IPR and KPI study programs which were initially less attractive. Qualitatively, the new building has adequate learning space, attracting every student to get the same facilities. Classrooms are equipped with air conditioning and soft chairs provide comfort in learning. Under the data on the increase in the number of students in study programs that previously lacked interest, in 2020 the demand for students increased significantly.

Increase in the Number of Students after the Merger

\section{Tabel. 1 Increase in the Number of Students after the Merger}

\begin{tabular}{lll}
\hline Tahun & HKI & KPI \\
\hline $\mathbf{2 0 1 9}$ & 5 & 10 \\
$\mathbf{2 0 2 0}$ & 25 & 40 \\
\hline
\end{tabular}

\section{CONCLUSSION}

In Indonesia, the quantity of universities does not correspond to the quality of those universities. In fact, universities that are less healthy were discovered. The Ministry of Education and Culture, through regulation number 7 of 2020, explains the establishment, change, and disbandment of PTS, as well as the establishment, change, and revocation of PTS licences, is the best step. The Ministry of Religion, along with the Ministry of Education and Culture, welcomed this by publishing Decree No. 3069 of the Directorate of Higher Education addressing technical rules for permissions for the formation, alteration, and revocation of permits for private Islamic 
religious colleges. Both ministries appointed sections under their departments as technical implementers. The Ministry of Education and Culture appointed the Directorate of Higher Education (DIKTI), and the Indonesian Ministry of Religion appointed the Directorate of Islamic Higher Education (DIKTIS). The merging of STAI and the University of Muhammadiyah Bandung resulted in an empirical investigation that resulted in the enactment of these laws. The first two ministries of Muhammadiyah University officially submitted an application for the unification of STAI to the Ministry of Education and Culture, and DIKTI issued an official unification letter after the procedure was passed. This formal letter was then used to submit an application to the Ministry of Religion for the unification of STAI - University; in this case, the submission letter was addressed to the Directorate of Islamic Education. The process of bringing the two roofs together must be done in a timely manner. Therefore, an alternative as a way out of accelerating this merger should be offered by the competent authorities, so that universities can carry out their work according to the plan.

\section{REFERENCES}

Aulia Alfirzan, Yuris Nasri, N. G. (2021). Kebijakan Pendidikan Serta Kebijakan Implementasi Pendidikan. Pendidikan Tambusai, 5 Nomor 1, 1521-1529. Retrieved from https://jptam.org/index.php/jptam/article/view/1131/1013

Creswell, J. (2015). Riset Pendidikan , Perencanaan, Pelaksanaan, dan Evaluasi Riset Kualitatif \& Kuantitatif.

Eka Prihatin Disas. (2017). Analisis Kebijakan Pendidikan Mengenai Pengembangan dan Peningkatan Profesi Guru. Penelitian Pendidikan, 17 Nomor 2, 158-166. Retrieved from https://docs.google.com/document/d/1ENtZ4LbNp2WqDomh1Cxk0aYEQFSC3VeQ UXx7JdoHpKU/edit?usp=sharing

Elwijaya Fadiyah, Vivi Mairina, N. G. (2021). Konsep Dasar Kebijakan Pendidikan. IICET, 6 Nomor 1(Kebijakan Pendidikan), 67-71. https://doi.org/DOI: https://doi.org/10.29210/3003817000

La Mahidin. (2018). Kebijakan Pendidikan Islam di Indonesia. UIN Maulana Malik Ibrahim Malang.

Nur Khoiri. (2016). Peningkatan Mutu Pendidikan Di Perguruan Tinggi Melalui Implementasi Total Quality Management (TQM). Jurnal Intelegensia, 4 No 1, 40-61. Retrieved from https://ejournal.unisnu.ac.id/JI/article/view/1355/1357

Nanang Fattah. (2014). Analisis Kebijakan Pendidikan. Jakarta: Rosdakarya.

Neuman, W. L. (2013). Metode Penelitian Sosial: Pendekatan Kualitatif dan Kuantitatif Edisi Ketujuh. Jakarta: PT. Indeks.

Ni Nyoman Resmi, N. K. A. M. (2017). Pengembangan Perguruan Tinggi Swasta Melalui Analisa SWOT. Bali.

Nugroho, R. (2017). Public Policy: Dinamika Kebijakan, Analisis Kebijakan, dan Manajemen Politik Kebijakan Publik. Jakarta: Elex Media Komputindo.

Paraden Lucas Sidauruk. (2013). Peranan Komunikasi Dalam Implementasi Kebijakan Pusat Layanan Internet Kecamatan (Kasus Di Provinsi Kepulauan Bangka Belitung). Penelitian Pos Dan Informatika, 3 No. 1 S, 81-113.

Sitti Rabiah. (2019). Manajemen Pendidikan Tinggi Dalam Meningkatkan Mutu Pendidikan. Sinar Manjemen, 6 No 6 1, 58-67. Retrieved from https://jurnal.unismuhpalu.ac.id/index.php/JSM/article/view/551/449

Widya Sari, Andi Muhammad Rifki, M. K. (2020). Analisis Kebijakan Terkait Implementasi Pembelajaran Jarak Jauh.

Idrus, M. (2014). Evaluasi Kebijakan Pemerintah Dalam Penyelenggaraan Pendidikan Agama Islam. El-Tarbawi. https://doi.org/10.20885/tarbawi.vol7.iss1.art7 
Josua Tarigan, Phd, CFP, CMA, CSRA, C., Swenjiadi Yenewan, S., \& Grace Natalia, S. (2016). Merger \& Akuisisi. Yogyakarta: Ekuilibria.

Rokim. (2019). Analisis Kebijakan Versi Dunn \& Implementasinya dalam Pendidikan Islam. PANCAW AHANA: Jurnal Studi Islam.

Serfiyani, C. Y. (2020). Restrukturisasi Perguruan Tinggi Swasta Sebagai Upaya Penyehatan Dan Peningkatan Kualitas Institusi. Jurnal Hukum Ius Quia Iustum. https://doi.org/10.20885/iustum.vol27.iss2.art10

Sumarto. (2017). Perkembangan Politik Dan Kebijakan Pendidikan Islam Di Indonesia. THAQÄFIYY ATT, 18, 107.

Solichin Abdul Wahab. (2013). Pengantar Analisis Kebijaksanaan Negara. Bandung: Rineka Cipt.

Yanita Petriella. (, August). PENDIDIKAN TINGGI: Terlalu Banyak PTS di Indonesia, Berkah Atau Musibah? Bisnis.Com. Retrieved from https://ekonomi.bisnis.com/read/20190808/12/1134160/pendidikan-tinggi-terlalubanyak-pts-di-indonesia-berkah-atau-musibah 